ISSN 1112-9867

\title{
BIODEGRADATION OF CARBAMAZEPINE USING FUNGI AND BACTERIA
}

\author{
N. M. Nasir ${ }^{1}$, S. A. Talib ${ }^{2}$, S. N. Hashim ${ }^{3}$ and C. C. Tay ${ }^{1,2, *}$ \\ ${ }^{1}$ Faculty of Applied Science, UniversitiTeknologi MARA, 40450 Shah Alam, Selangor, \\ Malaysia \\ ${ }^{2}$ Faculty of Civil Engineering, UniversitiTeknologi MARA, 40450 Shah Alam, Selangor, \\ Malaysia \\ ${ }^{3}$ Faculty of Applied Science, UniversitiTeknologi MARA, 35400Tapah, Perak, Malaysia
}

Published online: 10 November 2017

\begin{abstract}
Carbamazepine is an anti-epileptic pharmaceuticalcompound which is frequently detected in wastewater. However, this compound is hardly degraded naturally due to its persistency. Thus, carbamazepine presents in water stream and household water supply as well as wastewater treatment plant. This paper focuses on various species of fungi and bacteria used in carbamazepine biodegradation and the carbamazepine degrading-enzymes involved in the degradation pathways. Selected research papers on carbamazepine biodegradation using fungi and bacteria were reviewed. The efficiency and approaches in term of methodologies and technologies used were highlighted in this paper. Such study sheds light on gaps of study and future research direction on carbamazepine biodegradation.
\end{abstract}

Keywords: biodegradation; carbamazepine; method; pharmaceuticals.

Author Correspondence, e-mail: taychiay@gmail.com

doi: http://dx.doi.org/10.4314/jfas.v9i6s.12 


\section{INTRODUCTION}

Emerging pollutants are new chemicals without regulatory status and the impacts on health and environment are poorly understood [1]. An example of emerging pollutants is pharmaceutical carbamazepine.

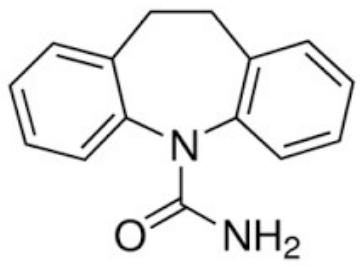

Fig.1. Carbamazepine structure

Carbamazepine (5H-dibenzo[b,f]azepine-5-carboxamide) is an anticonvulsant pharmaceutical commonly used in treatment of epilepsy, bipolar disorder, schizophrenia and trigeminal neuralgia [2]. Upon consumption by patients, approximately $72 \%$ of carbamazepine was absorbed, metabolized and excreted through urine. However, $28 \%$ failed to transform and discharged into water through faeces[3]. This compound eventually flows into wastewater.

Carbamazepine is frequently detected in wastewater and difficult to be degraded due to its complex structure and resistance to biodegradation [3]. Current wastewater treatment plants are not designed for removal of pharmaceuticals. Thus, this compound presents in treated wastewater at concentration ranging from $\mathrm{ng}^{-1}$ to $\mu \mathrm{gL}^{-1}[2]$.

Carbamazepine in wastewater causes negative effects to environment and animals. Carbamazepine was detected in embryo of pregnant mice when the mother was exposed to environmental concentration of carbamazepine through drinking water [4]. Exposure of carbamazepine on fish Jenynsiamultidentata caused irregular cortisol activity and aggressive behaviour[5]. A study conducted on other fishes species Pimephalesnotatus and Ictaluruspunctatus showed detection of carbamazepine in brain, liver, plasma and white muscle after exposed to carbamazepine for 28 days [2]. Another study on insect, midge Chironomusriparius showed an increase in mortality of the species when carbamazepine was applied [6]. Since various studies demonstrated that carbamazepine causes adverse effects on animals, biodegradation of this compound is crucial to protect animals and the environment. Biodegradation is an effective method for carbamazepine degradation [3]. However, complete degradation of this compound is hardly achieved. This paper focuses on efficiency of 
carbamazepine biodegradation using variety of fungi and bacteria. Both fungi and bacteria have extracellular enzymes that function to cleave the complex compound bonds, hence reducing carbamazepine concentration. This paper also provides list of carbamazepine-degrading enzymes involve in biodegradation.

\section{BIODEGRADATION USING FUNGI}

Biodegradation of carbamazepine using fungi is conducted since fungi are known to have capabilities in degrading persistent pollutants [7]. The fungi species used in carbamazepine biodegradation include Trichodermaharzianum[8], Pleurotusostreatus (normal strain [8], AC9 [9]), immobilized Trametesversicolor[10], Trametesversicolor (ATCC [11], ATCC 42530 [12], ATCC 7731 [13] and NRRL 66313 [14] ), Aspergillusniger[15], Cunninghamellaelegans ATCC 9254 [16], Umbelopsisramanniana R-56 [16] andPhanerochaetechrysosporium (mobilized strain F-1767 [17] and immobilized strain F-1767 [18] ).

Summary of carbamazepine degradation by fungi according to species is listed in Table 1 . Efficiency, different types of system applied, experimental condition and enzyme involved were discussed in following sections.

Table 1.Fungal degradation of carbamazepine

\begin{tabular}{|c|c|c|c|c|c|}
\hline Fungi & Efficiency & System Applied & Condition & $\begin{array}{l}\text { Enzyme } \\
\text { Involved }\end{array}$ & $\begin{array}{c}\text { Refere } \\
\text { nces }\end{array}$ \\
\hline $\begin{array}{l}\text { Trichoder } \\
\text { maharzia } \\
\text { num }\end{array}$ & $72 \%$ & $\begin{array}{c}\text { Culture: Batch flask } \\
\text { Extraction: SPE HLB } \\
\text { cartridge } \\
\text { Analysis: Liquid } \\
\text { chromatography-high } \\
\text { resolution tandem } \\
\text { mass spectrometry }\end{array}$ & $\begin{array}{l}\text { Initial concentration: } \\
\qquad 4 \mu \mathrm{gL}^{-1} \\
\text { Period: } 15 \text { days } \\
\text { Temperature: } 25^{\circ} \mathrm{C} \\
\text { pH: } 7.6 \\
\text { Medium: Murashige } \\
\text { and Skoog media } \\
\text { (liquid) }\end{array}$ & $\begin{array}{l}\text { Cytochrom } \\
\text { e P450 } \\
\text { enzymes }\end{array}$ & [8] \\
\hline $\begin{array}{l}\text { Pleurotus } \\
\text { ostreatus }\end{array}$ & $68 \%$ & $\begin{array}{l}\text { Culture: Batch flask } \\
\text { Extraction: SPE HLB }\end{array}$ & $\begin{array}{l}\text { Initial concentration: } \\
\qquad 4 \mu \mathrm{gL}^{-1}\end{array}$ & $\begin{array}{c}\text { Cytochrom } \\
\text { e P450 }\end{array}$ & [8] \\
\hline
\end{tabular}




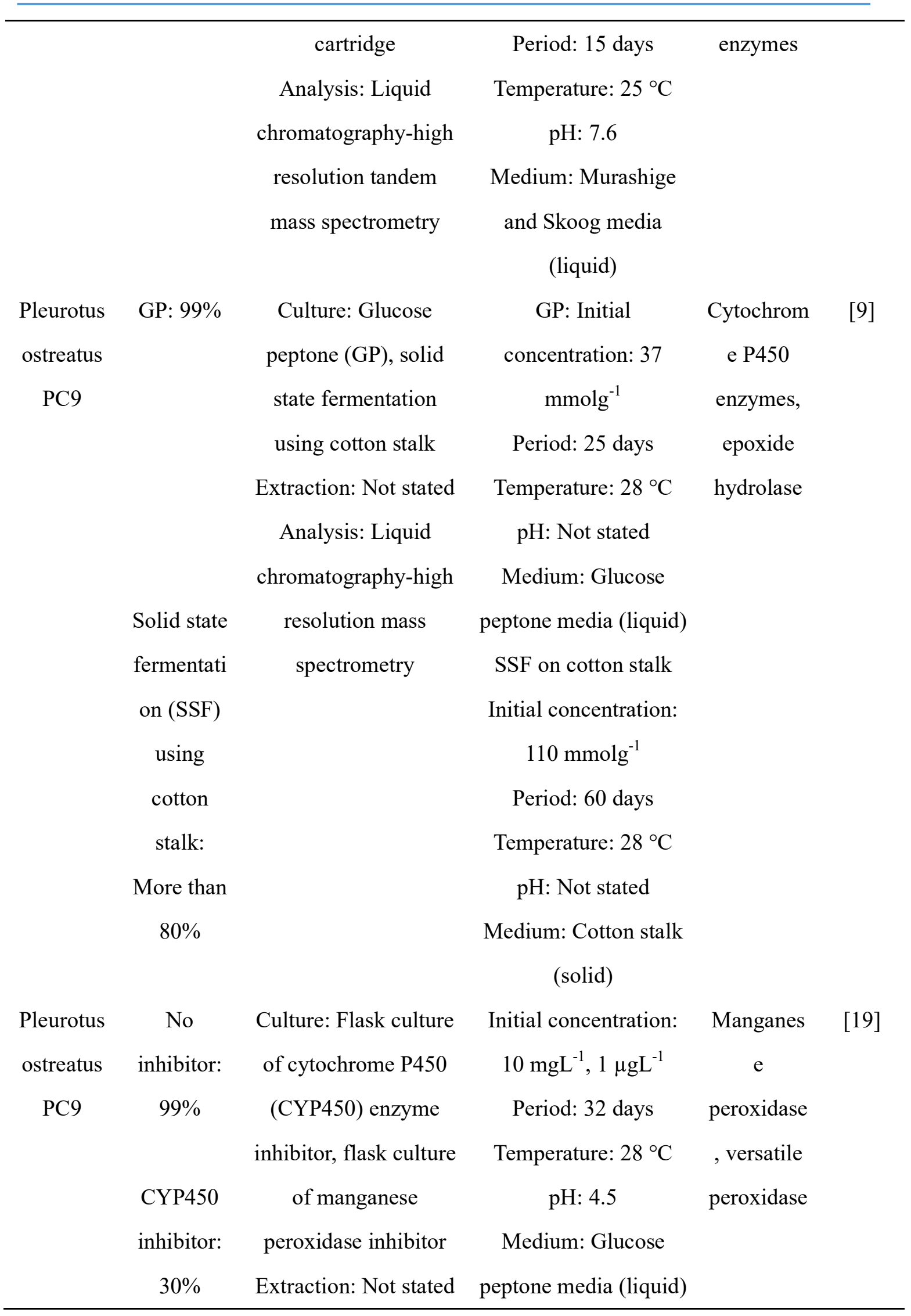




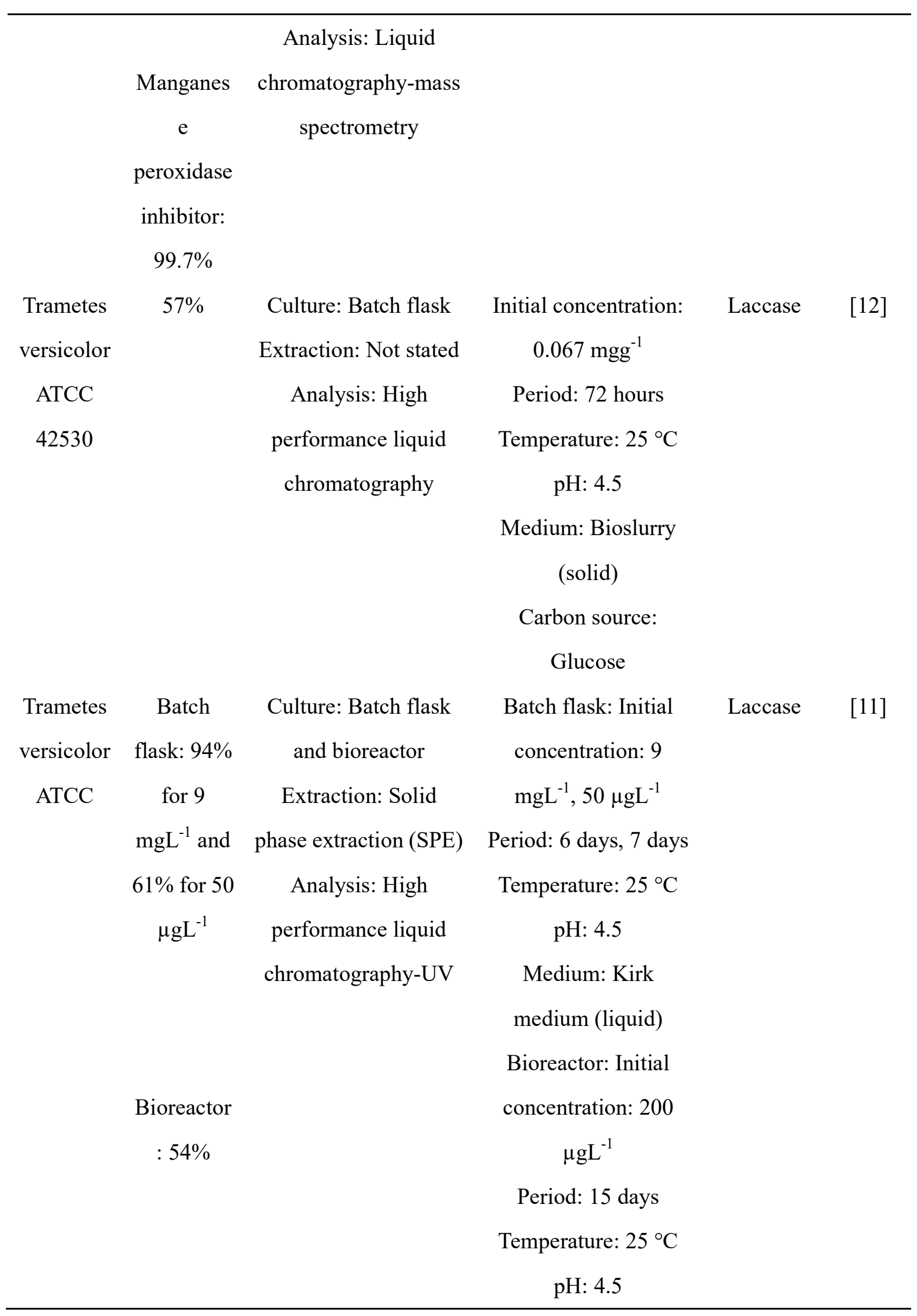




\section{Medium: Kirk}

medium (liquid)

Carbon source:

Glucose

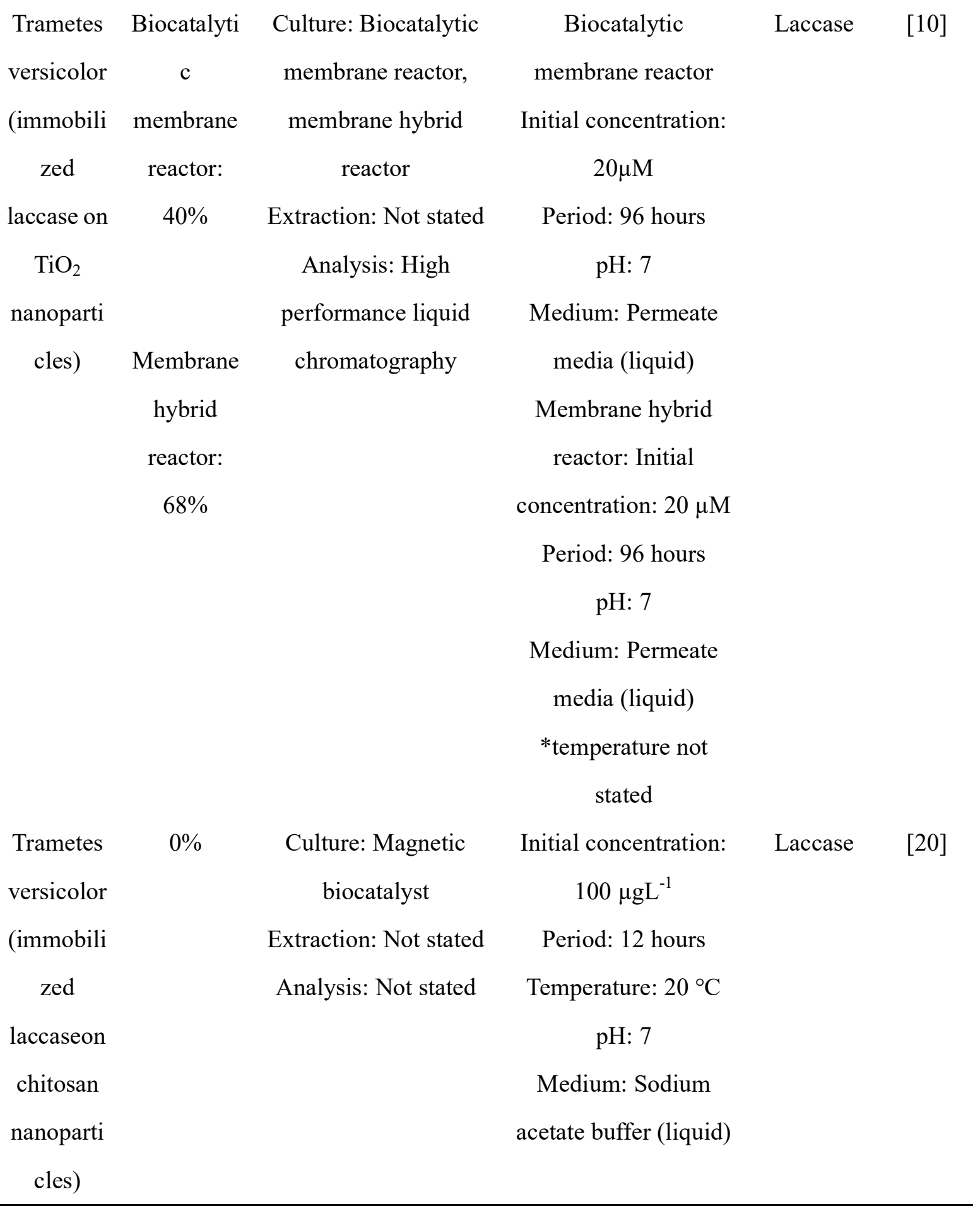




\begin{tabular}{|c|c|c|c|c|c|}
\hline $\begin{array}{l}\text { Trametes } \\
\text { versicolor }\end{array}$ & $\begin{array}{c}\text { Less than } \\
60 \%\end{array}$ & $\begin{array}{c}\text { Culture: Aerated batch } \\
\text { reactor }\end{array}$ & $\begin{array}{l}\text { Initial concentration: } \\
\qquad 350 \mu \mathrm{gL}^{-1}\end{array}$ & $\begin{array}{l}\text { Laccase, } \\
\text { lignin }\end{array}$ & {$[14]$} \\
\hline NRRL & & Extraction: & Period: 8 days & peroxidase & \\
\hline \multirow[t]{10}{*}{66313} & & Liquid-liquid & Temperature: $25 \pm$ & and & \\
\hline & & extraction & $2{ }^{\circ} \mathrm{C}$ & manganese & \\
\hline & & Analysis: High & pH: 4.5 & peroxidase & \\
\hline & & performance liquid & Medium: Kirk media & & \\
\hline & & chromatography-phot & (liquid) & & \\
\hline & & odiode array detection, & Carbon source: & & \\
\hline & & gas & glucose $\left(5 \mathrm{gL}^{-1}\right)$ & & \\
\hline & & chromatography-time- & & & \\
\hline & & of-flight mass & & & \\
\hline & & spectrometry & & & \\
\hline Trametes & $10 \%$ & Culture: Batch flask & Initial concentration: & Laccase & [13] \\
\hline versicolor & & Extraction: Not stated & $930 \mu \mathrm{gL}^{-1}$ & & \\
\hline ATCC & & Analysis: High & Period: 22 hours & & \\
\hline \multirow[t]{3}{*}{7731} & & performance liquid & Temperature: $25^{\circ} \mathrm{C}$ & & \\
\hline & & chromatography-UV & $\mathrm{pH}: 4.5$ & & \\
\hline & & & Medium: Liquid & & \\
\hline Cunningh & $43 \%$ & Culture: Batch flask & Initial concentration: 1 & Not stated & {$[16]$} \\
\hline amellaele & & Extraction: Ethyl & $\mu \mathrm{M}$ & & \\
\hline gans & & acetate and sodium & Period: 25 days & & \\
\hline ATCC & & sulphate & Temperature: $28^{\circ} \mathrm{C}$ & & \\
\hline \multirow[t]{6}{*}{9254} & & Analysis: High & $\mathrm{pH}$ : Not stated & & \\
\hline & & performance liquid & Medium: Potato & & \\
\hline & & chromatography, & dextrose broth (liquid) & & \\
\hline & & liquid & & & \\
\hline & & chromatography-mass & & & \\
\hline & & spectrometry & & & \\
\hline
\end{tabular}




\begin{tabular}{|c|c|c|c|c|c|}
\hline $\begin{array}{l}\text { Umbelop } \\
\text { sisramann }\end{array}$ & $26 \%$ & $\begin{array}{l}\text { Culture: Batch flask } \\
\text { Extraction: Ethyl }\end{array}$ & $\begin{array}{c}\text { Initial concentration: } 1 \\
\qquad \mu \mathrm{M}\end{array}$ & Not stated & {$[16]$} \\
\hline \multirow[t]{8}{*}{ iana R-56 } & & acetate and sodium & Period: 25 days & & \\
\hline & & sulphate & Temperature: $28^{\circ} \mathrm{C}$ & & \\
\hline & & Analysis: High & $\mathrm{pH}$ : Not stated & & \\
\hline & & performance liquid & Medium: Potato & & \\
\hline & & chromatography, & dextrose broth (liquid) & & \\
\hline & & liquid & & & \\
\hline & & chromatography-mass & & & \\
\hline & & spectrometry & & & \\
\hline Phaneroc & $60-80 \%$ & Culture: Sequence & Initial concentration: 5 & Lignin & {$[17]$} \\
\hline haetechry & & plate bioreactor & $\mathrm{mgL}^{-1}$ and $1 \mathrm{mgL}^{-1}$ & peroxidase & \\
\hline sosporiu & & Extraction: $0.25 \mu \mathrm{m}$ & Period: 100 days & , & \\
\hline $\mathrm{m} \mathrm{BKM}$ & & membrane & Temperature: $34-37{ }^{\circ} \mathrm{C}$ & manganese & \\
\hline \multirow[t]{3}{*}{ F-1767 } & & Analysis: High & pH: Not stated & peroxidase & \\
\hline & & performance liquid & Medium: Kirk media & & \\
\hline & & chromatography & (liquid) & & \\
\hline Phaneroc & $80 \%$ & Culture: & Initial concentration: & Manganes & {$[21]$} \\
\hline haetechry & & Countercurrent & $1000 \mu \mathrm{gL}^{-1}$ & $\mathrm{e}$ & \\
\hline sosporiu & & seepage bioreactor & Period: 165 days & peroxidase & \\
\hline $\mathrm{m} \mathrm{BKM}$ & & Extraction: Not stated & Temperature: $30^{\circ} \mathrm{C}$ & & \\
\hline F-1767 & & Analysis: High & pH: Not stated & & \\
\hline (immobili & & performance liquid & Medium: Modified & & \\
\hline zed) & & chromatography & Kirk media (liquid) & & \\
\hline Phaneroc & More than & Culture: Rotating & Initial concentration: & Lignin & {$[18]$} \\
\hline haetechry & $90 \%$ & suspension cartridge & $1000 \mu \mathrm{gL}^{-1}$ & peroxidase & \\
\hline sosporiu & & reactor & Period: 160 days & , & \\
\hline $\mathrm{m} \mathrm{BKM}$ & & Extraction: Not stated & Temperature: $25^{\circ} \mathrm{C}$ & manganese & \\
\hline F-1767 & & Analysis: High & $\mathrm{pH}$ : Not stated & peroxidase & \\
\hline
\end{tabular}




\begin{tabular}{|c|c|c|c|c|c|}
\hline (immobili & & performance liquid & Medium: Modified & & \\
\hline zed) & & chromatography & Kirk media (liquid) & & \\
\hline \multirow{10}{*}{$\begin{array}{l}\text { Aspergill } \\
\text { usniger }\end{array}$} & $9 \%$ & Culture: Batch flask & Initial concentration: & Not stated & {$[15]$} \\
\hline & & culture & $11.4 \mathrm{mgL}^{-1}$ & & \\
\hline & & Extraction: & Period: 7 days & & \\
\hline & & Centrifugation (retain & Temperature: $26^{\circ} \mathrm{C}$ & & \\
\hline & & supernatant) & pH: Not stated & & \\
\hline & & Analysis: High & Medium: Minimum & & \\
\hline & & performance liquid & mineral salt media & & \\
\hline & & chromatography-diode & (liquid) & & \\
\hline & & array detector & Additional carbon: 3 & & \\
\hline & & & $\mathrm{gL}^{-1}$ glucose & & \\
\hline
\end{tabular}

\subsection{Efficiency of Fungi Degradation According to Methods}

Different types of methods used in carbamazepine biodegradation include batch culture, bioreactor, biocatalyst and solid state fermentation.

\subsubsection{Batch Culture}

Fungi Trichodermaharzianum degraded $72 \%$ of carbamazepine within 15 days, meanwhile Pleurotusostreatus degraded $68 \%$ of the compound within 15 days at similar condition in Murashige and Skoog media [8]. Another study conducted by [9] showed Pleurotusostreatus of strain PC9 managed to degrade $99 \%$ of carbamazepine in 25 days when glucose peptone (GP) media was used for degradation experiment. Another study also showed consistent result where Trametesversicolor strain ATCC 42530 degraded 57\% of carbamazepine within 72 hours in bioslurry medium with glucose as additional carbon source [12].

Different types of media affect degradation efficiency. Since Murashige and Skoog media contains limited minerals, fungi utilize carbamazepine as sole carbon source immediately for growth and result in fast degradation. Glucose peptone contains carbon source for fungi growth. Thus, fungi in this media utilized both carbon source from glucose peptone and carbamazepine slowly, resulted in slower but higher degradation percentage.Fungi Aspergillusniger reported only managed to degrade $9 \%$ of carbamazepine after 7 days eventhough additional carbon of $3 \mathrm{gL}^{-1}$ glucose was added [15]. This reveals that different 
types of fungi species require different types of carbon source.

For effects of enzymes on carbamazepine degradation, fungi Pleurotusostreatus PC9 demonstrated 99\% carbamazepine degradation within 32 days when enzyme inhibitor was absence in the culture. When enzyme inhibitors were added, degradation efficiency changed. The culture with cytochrome P450 enzyme inhibitor experienced reduction in degradation efficiency resulted in only $30 \%$ degradation. Favourably, another system with manganese peroxidase inhibitor resulted in a slight increment with degradation efficiency of $99.7 \%$ [19]. This suggests that addition of enzyme inhibitor has positive or negative effect on fungi carbamazepine degradation as it depends on fungi metabolism system.

Next, there are also studies that investigated the effect of different initial concentration on degradation efficiency. FungiTrametesversicolor of strain ATCC resulted in $94 \%$ of $9 \mathrm{mgL}^{-1}$ carbamazepine degradation within 6 days. However, this fungi species only degraded $61 \%$ of $50 \mu \mathrm{gL}^{-1}$ carbamazepine at similar condition [11]. It can be hypothesized that high concentration of carbamazepine provided more carbon source, hence the degradation was more efficient. Another study also showed relatively the similar findings where Trametesversicolor of strain ATCC 7731 managed to degrade only 10\% of low concentration $930 \mu \mathrm{gL}^{-1}$ carbamazepine within 22 hours [13].

There is also study that investigated the potential of non-ligninolytic and ligninolytic fungi for carbamazepine degradation. Fungi Cunninghamellaelegans ATCC 9254 and Umbelopsisramanniana R-56 resulted in only $43 \%$ and $26 \%$ of carbamazepine degradation respectively after 25 days at similar condition [16]. The result showed non-ligninolytic fungi only capable to degrade less than 50\% degradation. From the study, it can be hypothesized that ligninolyticfungi was more efficient in degrading carbamazepine where the efficiency reached 99\% when ligninolytic fungi Pleurotusostreatus was used [19].

\subsubsection{Bioreactor}

Different types of bioreactor used in carbamazepine biodegradation include:

\subsubsection{Standard Bioreactor}

Trametesversicolor ATCC resulted in 54\% carbamazepine degradation after 15 days with glucose as additional carbon source [11]. 


\subsubsection{BiocatalyticMembrane Bioreactor}

Laccase of Trametesversicolor immobilized on titanium oxide $\left(\mathrm{TiO}_{2}\right)$ only resulted in $40 \%$ carbamazepine degradation after 96 hours [10].

\subsubsection{Membrane Hybrid Bioreactor}

Laccase of Trametesversicolor immobilized on titanium oxide $\left(\mathrm{TiO}_{2}\right)$ resulted in $68 \%$ carbamazepine degradation at similar condition as biocalytic membrane bioreactor [10].

\subsubsection{Aerated Batch Bioreactor}

TrametesversicolorNRRL 66313 degraded less than 60\% carbamazepine after 8 days. Additional carbon source of $5 \mathrm{gL}^{-1}$ glucose was supplied [14].

\subsubsection{Sequence Plate Bioreactor}

Fungi Phanerochatechrysosporium BKM F-1767 resulted in 60-80\% carbamazepine degradation after 100 days [17].

\subsubsection{Countercurrent Seepage Bioreactor}

Immobilized Phanerochatechrysosporium BKM F-1767 degraded 80\% of carbamazepine within 165 days [21].

\subsubsection{Rotating Suspension Cartridge Bioreactor}

Immobilized Phanerochatechrysosporium BKM F-1767 managed to degrade more than 90\% of carbamazepine after 160 days [18].

\subsubsection{Biocatalyst}

Magnetic biocatalyst was conducted using immobilized laccase of Trametesversicolor on chitosan nanoparticles failed to degrade carbamazepine after 12 hours [20].

\subsubsection{Solid State Fermentation}

Fungi Pleurotusostreatus PC9 was used for solid state fermentation using cotton stalk and able to degrade more than $80 \%$ carbamazepine after 60 days [9].

\subsubsection{Summary}

Among all methods used in degradation of carbamazepine using fungi, Pleurotusostreatus in batch culture was the most effective where 99\% degradation was achieved. Membrane hybrid bioreactor was also effective since laccase of fungi Trametesversicolor capable to degrade carbamazepine with $60 \%$ efficiency within short time which was 96 hours. Sequence plate 
bioreactor, countercurrent seepage bioreactor, rotating suspension cartridge bioreactor and solid state fermentation using cotton stalk also resulted in high degradation efficiency. However, these experimental methods were time consuming.

\subsection{Carbamazepine Degrading Enzymes from Fungi}

Carbamazepine-degrading enzymes produced by fungi include:

- Cytochrome P450 enzyme [8, 19]

- Manganese peroxidase [14, 17-19]

- Versatile peroxidase [19]

- Laccase[10-14, 20]

- Lignin peroxidase $[14,18,22]$

All of the conducted studies on carbamazepine degrading enzymes are qualitative study. These enzymes play important role in carbamazepine degradation pathways. A study by [16] proposed that carbamazepine degraded through mixed mono-oxidation reactions (hydroxylation and epoxidation). Both fungi Cunninghamellaelegans ATCC 9254 and Umbelopsisramanniana R-56 produced 10,11-dihydro-10,11-epoxycarbamazepine (CBZ-EP) as major metabolite and 3-hydroxycarbamazepine as one of the minor metabolites. C. elegans also produced 2-hydroxycarbamazepine, while U. ramanniana exhibited new metabolites of hydroxycarbamazepine and 4-hydroxycarbamazepine.

Another study proposed a detailed pathway, where 24 metabolites were identified during carbamazepine degradation [9]. The three pathways involved were oxidation, hydrolysis and methoxylation. The main pathway was oxidation of carbamazepine into 10,11-dihydro-10,11-epoxycarbamazepine (CBZ-EP). This reaction was aided by enzymes cytochrome oxidase and manganese peroxidase. Then, hydrolysis reaction converted the metabolite to dihydroxide carbamazepine (diOH-CBZ). It was suggested that epoxide hydrolase involved in this reaction. The process was followed by methoxylation resulting in formation of 10-methoxy-carbamazepine. The major metabolite identified in this study is similar to [16].

\section{BIODEGRADATION USING BACTERIA}

Bacteria are also one of the microorganisms group which capable to degrade organic 
pollutants [7]. Since bacteria grow rapidly, application of this microorganism group can result in fast degradation of carbamazepine. Studies on biodegradation of carbamazepine using bacteria are limited. There were various carbamazepine biodegradation studies that utilized bacteria such as Streptomyces MIUG 4.89 [23-24], Streptomyces SNA [24], Serratia sp. [25], Rhodococcusrhodochrous[15], Pseudomonas CBZ-4 [3], mixed culture of Aquicella sp., Microvirga sp. and family Rhodobacteraceae[26], mixed culture of Spinghomonas sp., unclassified family of Spinghomonadaceae and Xanthomonandaceae[26], mixed culture of Acetinobacter US1, Bacillus halodurans, Micrococcus SBS-8 and Pseudomonas putida[27], mixed culture of Spinghobacterium sp., Chryseobacterium sp. and Alcaligenes sp. [28] and Paraburkholderiaxenovorans LB400 [29].

Table 2 showed summary of carbamazepine degradation by various bacteria species. This table is classified according to efficiency, different types of system applied, experimental condition and enzyme involved.

Table 2.Bacterial degradation of carbamazepine

\begin{tabular}{|c|c|c|c|c|c|}
\hline Bacteria & $\begin{array}{l}\text { Effici } \\
\text { ency }\end{array}$ & System Applied & Condition & $\begin{array}{l}\text { Enzyme } \\
\text { Involved }\end{array}$ & $\begin{array}{c}\text { Refere } \\
\text { nces }\end{array}$ \\
\hline \multirow{10}{*}{$\begin{array}{l}\text { Streptomyce } \\
\text { s MIUG } 4.89\end{array}$} & \multirow[t]{10}{*}{$30 \%$} & Culture: Batch reactor & Initial concentration: & \multirow[t]{10}{*}{ Not stated } & \multirow[t]{10}{*}[23]{} \\
\hline & & Extraction: & $0.2 \mathrm{mgL}^{-1}$ & & \\
\hline & & Centrifugation & Period: 7 days & & \\
\hline & & (supernatant retain) & Temperature: $25^{\circ} \mathrm{C}$ & & \\
\hline & & Analysis: High & $\mathrm{pH}: 6$ & & \\
\hline & & performance liquid & Medium: Basal & & \\
\hline & & \multirow[t]{4}{*}{ chromatography } & media (liquid) & & \\
\hline & & & Additional carbon: & & \\
\hline & & & $6.5 \mathrm{gL}^{-1}$ glucose, 2 & & \\
\hline & & & $\mathrm{gL}^{-1}$ yeast & & \\
\hline \multirow{3}{*}{$\begin{array}{l}\text { Streptomyce } \\
\text { s MIUG } 4.89\end{array}$} & \multirow[t]{3}{*}{$35 \%$} & Culture: Batch flask & Initial concentration: & Laccase & \multirow[t]{3}{*}[24]{} \\
\hline & & culture & $0.2 \mathrm{mgL}^{-1}$ & Phenoloxi & \\
\hline & & Extraction: Not stated & Period: 7 days & dase & \\
\hline
\end{tabular}




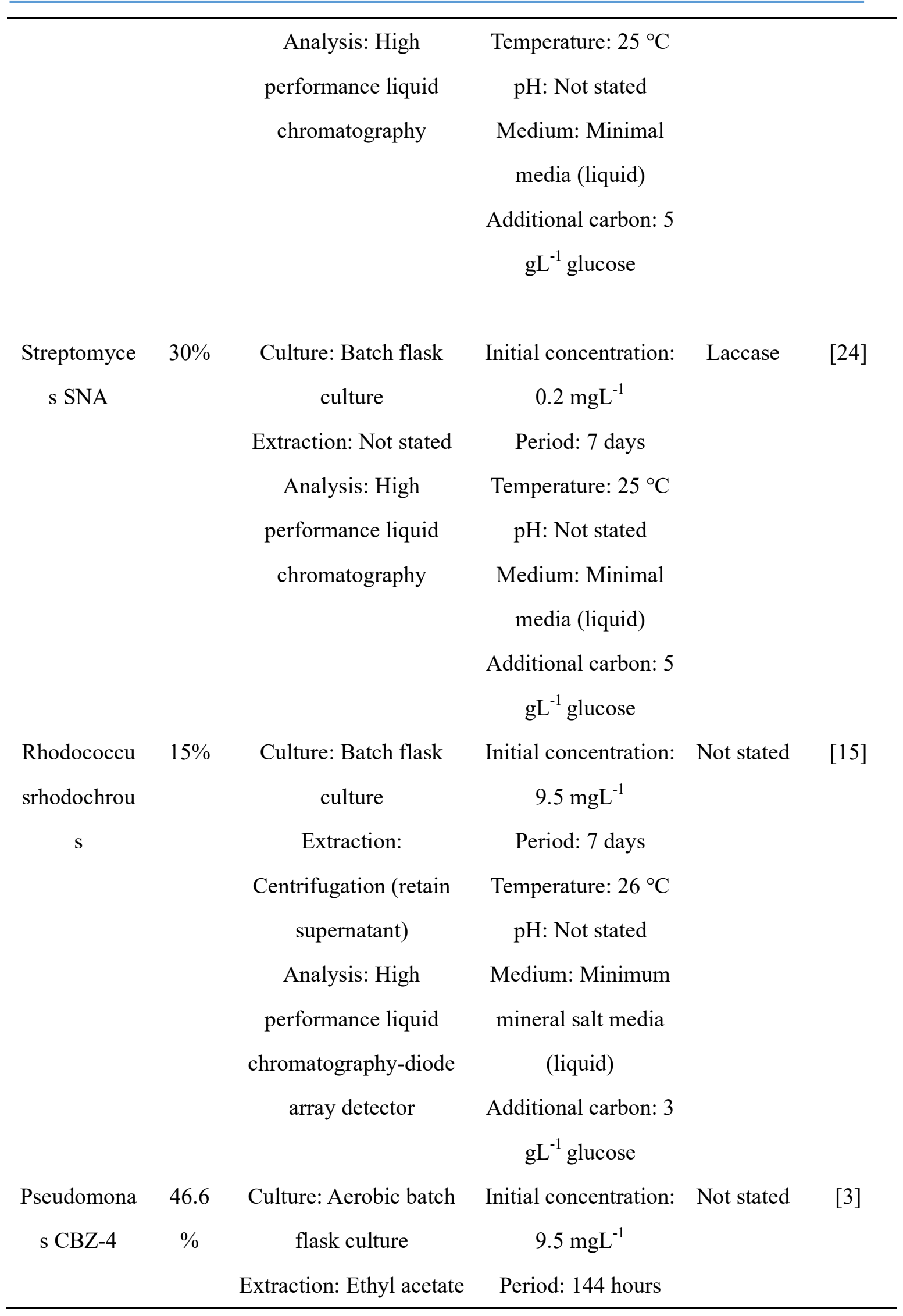




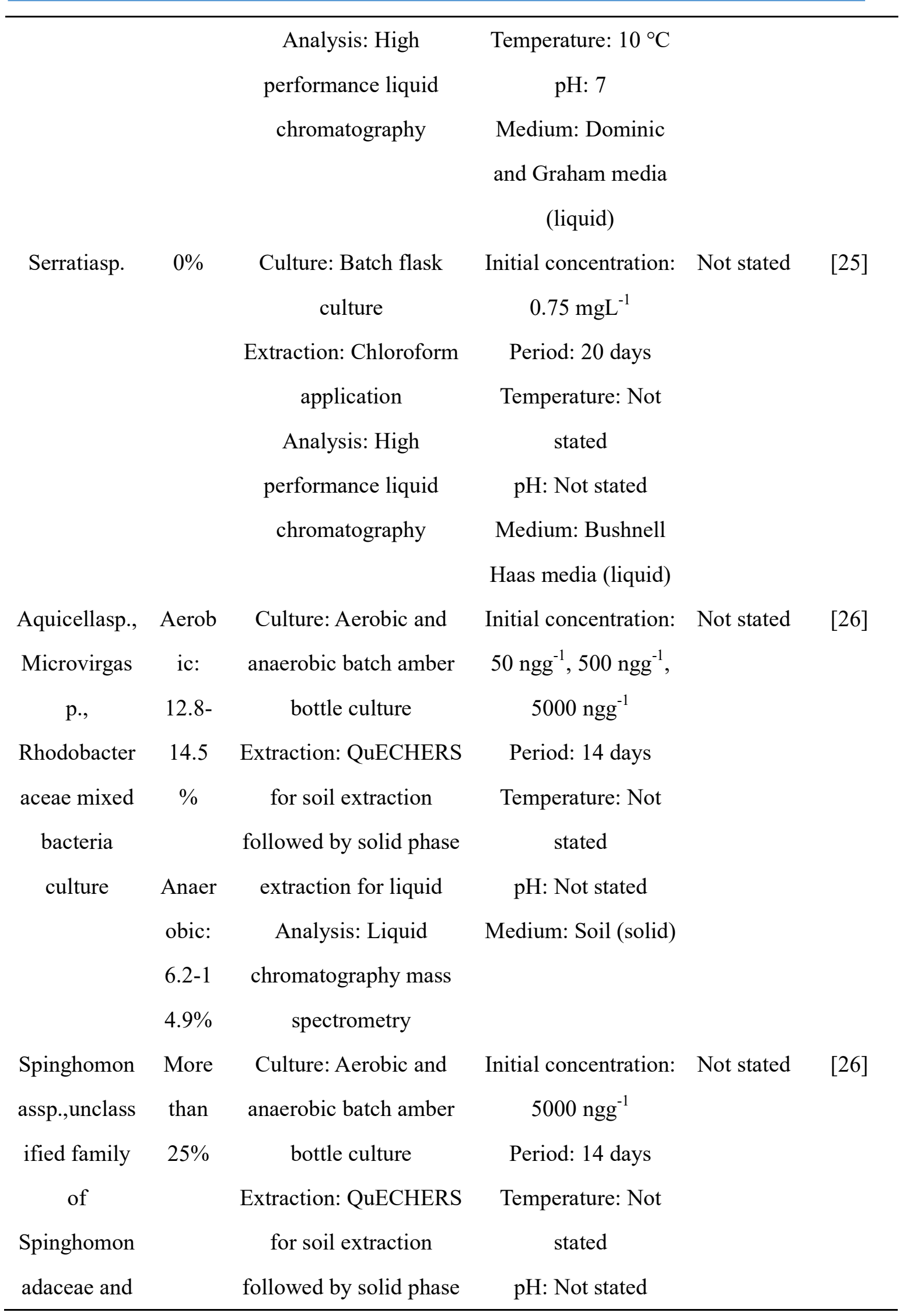




\begin{tabular}{|c|c|c|c|c|c|}
\hline Xanthomona & & extraction for liquid & Medium: Soil (solid) & & \\
\hline ndaceae & & Analysis: Liquid & & & \\
\hline mixed & & chromatography mass & & & \\
\hline bacteria & & spectrometry & & & \\
\hline \multicolumn{6}{|l|}{ culture } \\
\hline Acetinobacte & $60 \%$ & Culture: Batch flask & Initial concentration: & Not stated & {$[27]$} \\
\hline r US1., & & culture & $100 \mu \mathrm{gL}^{-1}$ & & \\
\hline Bacillus & & Extraction: Solid phase & Period: 12 days & & \\
\hline halodurans, & & extraction & Temperature: $30^{\circ} \mathrm{C}$ & & \\
\hline Micrococcus & & Analysis: High & $\mathrm{pH}: 7$ & & \\
\hline SBS-8, & & performance liquid & Medium: LB media & & \\
\hline Pseudomona & & chromatography & (liquid) & & \\
\hline \multicolumn{6}{|l|}{ s putida } \\
\hline \multicolumn{6}{|l|}{ mixed } \\
\hline \multicolumn{6}{|l|}{ bacteria } \\
\hline \multicolumn{6}{|l|}{ culture } \\
\hline Sphingobact & With & Culture: Batch flask & Initial concentration: & Not stated & {$[28]$} \\
\hline erium sp., & acetat & culture & $25 \mu \mathrm{gmL}^{-1}$ & & \\
\hline Chryseobact & e: & Extraction: Not stated & Period: 14 days & & \\
\hline erium sp., & $20 \%$ & Analysis: High & Temperature: $25{ }^{\circ} \mathrm{C}$ & & \\
\hline Alcaligeness & & performance liquid & pH: Not stated & & \\
\hline p. mixed & No & chromatography-diode & Medium: Minimal & & \\
\hline bacteria & acetat & array detector & media (liquid) & & \\
\hline \multirow[t]{2}{*}{ culture } & e: & & Additional carbon: & & \\
\hline & $10 \%$ & & $100 \mu \mathrm{gmL}^{-1}$ acetate & & \\
\hline Paraburkhol & $100 \%$ & Culture: Batch serum & Initial concentration: & Biphenyl & [29] \\
\hline deriaxenovor & & bottle culture (direct & $10 \mathrm{mgL}^{-1}$ & dioxygen & \\
\hline \multirow[t]{2}{*}{ ansLB400 } & & biological method) & Period: 24 hours & ase, & \\
\hline & & Extraction: Ethyl acetate & Temperature: $25^{\circ} \mathrm{C}$ & dihydrodi & \\
\hline
\end{tabular}




\begin{tabular}{ccc}
\hline Analysis: High & pH: 7 & ol \\
performance liquid & Medium: Phosphate & dehydrog \\
chromatography-diode & buffer (liquid) & enase \\
array detector, High & \\
performance liquid & \\
chromatography-mass & \\
spectrometry, gas & \\
chromatography-mass & \\
spectrometry & \\
\hline
\end{tabular}

\subsection{Efficiency of Bacteria Degradation According to Methods}

Different types of methods used in carbamazepine biodegradation using bacteria include batch flask culture, bioreactor, batch amber culture bottle and batch serum culture bottle.

\subsubsection{Batch Flask Culture}

Bacteria Streptomyces MIUG 4.89 degraded only 35\% carbamazepine during 7 days of experimental period when $5 \mathrm{gL}^{-1}$ of glucose was added as carbon source [24]. Meanwhile, bacteria Streptomyces SNA resulted in lower carbamazepine degradation which is $30 \%$ during similar experimental period and condition. Bacteria Rhodococcusrhodochrous managed to degrade only $15 \%$ of carbamazepine after 7 days eventhough additional carbon source of $3 \mathrm{gL}^{-1}$ glucose was added [15].Another study demonstrated that Pseudomonas CBZ-4 capable to degrade only $46.6 \%$ of carbamazepine after 144 hours period [3]. Bacteria Serratia sp. failed to degrade carbamazepine eventhoughit was cultured during a long period of 20 days [25].

Individual flask culture study was less efficient in degrading carbamazepine. None of the individual flaks culture study achieved more than 50\% degradation. Moreover, addition of carbon source did not enhance degradation of carbamazepine.

Next, mixed bacteria culure studies were also conducted. Mixed bacteria culture of Acetinobacter US1, Bacillus halodurans, Micrococcus SBS-8 and Pseudomonas putida degraded $60 \%$ of bacteria within 7 days of experimental period [27]. This revealed that mixed bacteria was more efficient compared to individual flask culture study. However, another mixed bacteria culture study of Spinghobacterium sp., Chryseobacterium sp. and Alcaligenes 
sp. only able to degrade $20 \%$ of carbamazepine when $100 \mu \mathrm{gmL}^{-1}$ of acetate was added as additional carbon source. Meanwhile, biodegradation efficiency decreased to $10 \%$ when acetate was absence [28]. Mixed bacteria culture may provide synergistic effects or antagonistic effects depending on bacteria species. Additional nutrient source effect study is limited and further investigation should be continued.

\subsubsection{Bioreactor}

Standard bioreactor was used to degrade carbamazepine using bacteria Streptomyces MIUG 4.89. This strain only degraded $30 \%$ of carbamazepine after 7 days with additional carbon source of $6.5 \mathrm{gL}^{-1}$ glucose and $2 \mathrm{gL}^{-1}$ yeast [23].

\subsubsection{Batch amber Bottle Culture}

Degradation experiment was conducted by comparing aerobic and anaerobic condition of batch amber bottle culture in soil medium. Mixed bacteria culture of Aquicella sp., Microvirga sp. and family Rhodobacteraceae only degraded $12.8-14.5 \%$ of carbamazepine in aerobic condition within 14 days and only degraded $6.2-14.9 \%$ of carbamazepine in anaerobic condition within the same experimental period and condition. Another mixed bacteria culture study of Spinghobacterium sp., Chryseobacterium sp. and Alcaligenes sp. only managed to degrade more than $25 \%$ of carbamazepine in soil medium within 14 days [26].

\subsubsection{Batch Serum Bottle Culture}

Bacteria Paraburkholderiaxenovorans LB400 achieved complete degradation of carbamazepine within 24 hours [29].

\subsubsection{Summary}

Based on various studies, different biodegradation methods have no significant effects on carbamazepine degradation by bacteria. Bacteria Paraburkholderiaxenovorans LB400 degraded $100 \%$ carbamazepine due to its ability to release various types of enzymes that play important roles in carbamazepine degradation. Mixed bacteria culture of Acetinobacter US1, Bacillus halodurans, Micrococcus SBS-8 and Pseudomonas putida also showed efficient degradation with $60 \%$ degradation rate. Other individual culture and mixed bacteria culture only degraded less than $50 \%$ carbamazepine. In mixed bacteria culture, there was limited nutrient, thus, bacteria die and resulted in inefficient degradation. Hence, bacteria characteristics and its adaptability in carbamazepine environment need to be determine before 
study is conducted.

\subsection{Carbamazepine Degrading Enzymes of Bacteria}

Carbamazepine-degrading enzymes produced by bacteria include:

- Laccase[24]

- Phenoloxidase[24]

- Biphenyl dioxygenase[29]

- Dihydrodiol dehydrogenase [29]

In [29] proposed a pathway of carbamazepine degradation by bacteria Paraburkholderiaxenovorans LB400. The main metabolites includecis-10,11-dihydroxy10,11-dihydrocarbamazepine and cis-2,3-dihydroxy-2,3-dihydrocarbamazepine. The enzyme involved was biphenyl dioxygenase. Further reaction utilized dihydrodiol dehydrogenase enzyme and coverted the cis-dihydrodiols into carbamazepine-diol and 2hydroxycarbamazepine. For laccase and phenoloxidase enzymes, the study only identified the presence of enzymes qualitatively hence, no pathway is proposed.

\section{CONCLUSION}

Various fungi and bacteria are capable in degrading carbamazepine. The difference in degradation efficiency is mainly affected by fungi and bacteria properties and its ability to release enzymes that aid in carbamazepine degradation. For fungi, different types of methods affect degradation efficiency. Meanwhile, for bacteria applications of advanced methods do not necessarily enhance the degradation efficiency. There are gaps of study in addition of carbon source utilization by both fungi and bacteria. Utilization of carbon source differs according to species. Thus, further study is needed on this topic. Next, for enzymes study, to authors' best knowledge, there is no proposed pathway that involved laccase enzyme in carbamazepine degradation using bacteria and fungi. Hence, detailed study on pathways involving this enzyme is needed. This study leads to further development and application of carbamazepine bioremediation. 


\section{ACKNOWLEDGEMENTS}

We acknowledge the financial support Fundamental Research Grant Scheme (FRGS) 600-RMI/FRGS 5/3 (26/2015) and facilities support from UniversitiTeknologi MARA.

\section{REFERENCES}

[1] Deblonde T, Cossu-Leguille C, Hartemann P. Emerging pollutants in wastewater: A review of the literature. International Journal of Hygiene and Environmental Health, 2011, 214(6):442-448

[2] Garcia S N, Foster M, Constantine L A, Huggett D. Field and laboratory fish tissue accumulation of the anti-convulsant drug carbamazepine. Ecotoxicology and Environmental Safety, 2012, 84:207-211

[3] Li A, Cai R, Cui D, Qiu T, Pang C, Yang J, Ma F, Ren N. Characterization and biodegradation kinetics of a new cold-adapted carbamazepine-degrading bacterium, Pseudomonas sp. CBZ-4. Journal of Environmental Sciences, 2013, 25(11):2281-2290

[4] Kaushik G, Huber D P, Aho K, Finney B, Bearden S, Zarbalis K S, Thomas M A. Maternal exposure to carbamazepine at environmental concentrations can cross intestinal and placental barriers. Biochemical and Biophysical Research Communications, 2016, 474(2):291-295

[5] Calcagno E, Durando P, Valdés M E, Franchioni L, Bistoni M de los Á. Effects of carbamazepine on cortisol levels and behavioral responses to stress in the fish Jenynsiamultidentata. Physiology and Behavior, 2016, 158:68-75

[6] Heye K, Becker D, Eversloh C L, Durmaz V, Ternes T A, Oetken M, Oehlmann J. Effects of carbamazepine and two of its metabolites on the non-biting midge Chironomusriparius in a sediment full life cycle toxicity test. Water Research, 2016, 98:19-27

[7] Haritash A K, Kaushik C P. Biodegradation aspects of Polycyclic Aromatic Hydrocarbons (PAHs): A review. Journal of Hazardous Materials, 2009, 169(1-3):1-15

[8] Buchicchio A, Bianco G, Sofo A, Masi S, Caniani D. Biodegradation of carbamazepine and clarithromycin by Trichodermaharzianum and Pleurotusostreatus investigated by liquid chromatography - high-resolution tandem mass spectrometry (FTICR MS-IRMPD). Science of the Total Environment, 2016, 557-558:733-739

[9] Golan-Rozen N, Seiwert B, Riemenschneider C, Reemtsma T, Chefetz B, Hadar Y. 
Transformation pathways of the recalcitrant pharmaceutical compound carbamazepine by the white-rot fungus Pleurotusostreatus: Effects of growth conditions. Environmental Science and Technology, 2015, 49(20):12351-12362

[10] Ji C, Hou J, Wang K, Zhang Y, Chen V. Biocatalytic degradation of carbamazepine with immobilized laccase-mediator membrane hybrid reactor. Journal of Membrane Science, 2016, 502:11-20

[11] Jelic A, Cruz-Morato C, Marco-Urrea E, Sarra M, Perez S, Vincent T, Petrovic M, Barcelo D. Degradation of carbamazepine by Trametesversicolor in an air pulsed fluidized bed bioreactor and identification of intermediates. Water Research, 2012, 46(4):955-964

[12] Rodríguez-Rodríguez C E, Marco-Urrea E, Caminal G. Degradation of naproxen and carbamazepine in spiked sludge by slurry and solid-phase Trametesversicolor systems. Bioresource Technology, 2010, 101(7):2259-2266

[13] Yang S, Hai F I, Nghiem L D, Roddick F, Price W E. Removal of trace organic contaminants by nitrifying activated sludge and whole-cell and crude enzyme extract of Trametesversicolor. Water Science and Technology, 2013, 67(6):1216-1223

[14] Shreve M J, Brockman A, Hartleb M, Prebihalo S, Dorman F L, Brennan R A. The white-rot fungus Trametesversicolor reduces the estrogenic activity of a mixture of emerging contaminants in wastewater treatment plant effluent. International Biodeterioration and Biodegradation, 2016, 109:132-140

[15] Gauthier H, Yargeau V, Cooper D G. Biodegradation of pharmaceuticals by Rhodococcusrhodochrous and AspergillusNiger by co-metabolism. Science of the Total Environment, 2010, 408(7):1701-1706

[16] Kang S I, Kang S Y, Hur H G. Identification of fungal metabolites of anticonvulsant drug carbamazepine. Applied Microbiology and Biotechnology, 2008, 79(4):663-669

[17] Zhang Y, Geißen S U. Elimination of carbamazepine in a non-sterile fungal bioreactor.Bioresource Technology, 2012, 112:221-227

[18] Li X, Xu J, de Toledo R A, Shim H. Enhanced carbamazepine removal by immobilized Phanerochaetechrysosporium in a novel rotating suspension cartridge reactor under non-sterile condition. International Biodeterioration and Biodegradation, 2016, 115:102-109 [19] Golan-Rozen N, Chefetz B, Ben-Ari J, Geva J, Hadar Y. Transformation of the 
recalcitrant pharmaceutical compound carbamazepine by Pleurotusostreatus: Role of cytochrome P450 monooxygenase and manganese peroxidase. Environmental Science and Technology, 2011, 45(16):6800-6805

[20] Kumar V V, Cabana H. Towards high potential magnetic biocatalysts for on-demand elimination of pharmaceuticals. Bioresource Technology, 2016, 200:81-89

[21] Li X, Xu J, de Toledo R A, Shim H. Enhanced removal of naproxen and carbamazepine from wastewater using a novel countercurrent seepage bioreactor immobilized with Phanerochaetechrysosporium under non-sterile conditions. Bioresource Technology, 2015, $197: 465-474$

[22] Zhang Y, Geißen S U. In vitro degradation of carbamazepine and diclofenac by crude lignin peroxidase. Journal of Hazardous Materials, 2010, 176(1-3):1089-1092

[23] PopaUngureanu C, Favier L, Bahrim G, Amrane A. Response surface optimization of experimental conditions for carbamazepine biodegradation by Streptomyces MIUG 4.89. New Biotechnology, 2015, 32(3):347-357

[24] Popa C, Favier L, Dinica R, Semrany S, Djelal H, Amrane A, Banrim G. Potential of newly isolated wild Streptomyces strains as agents for the biodegradation of a recalcitrant pharmaceutical, carbamazepine. Environmental Technology, 2014, 35(24):3082-3091

[25] Molina C, Benitez N, Simarro R, Bautista L, Vargas C, Cambero G, Diaz M, Quijano M. Bioremediation techniques for naproxen and carbamazepine elimination: Toxicity evaluation test. ChimicaOggi-Chemistry Today, 2016, 34(2):52-55

[26] Thelusmond J R, Strathmann T J, Cupples A M. The identification of carbamazepine biodegrading phylotypes and phylotypes sensitive to carbamazepine exposure in two soil microbial communities. Science of the Total Environment, 2016, 571:1241-1252

[27] Ha H, Mahanty B, Yoon S, Kim C G. Degradation of the long-resistant pharmaceutical compounds carbamazepine and diatrizoate using mixed microbial culture. Journal of Environmental Science and Health, Part A, 2016, 51(6):467-471

[28] Ribeiro A R, Gonçalves V M F, Maia A S, Carvalho M F, Castro P M L, Tiritan M E. Microbial degradation of pharmaceuticals followed by a simple HPLC-DAD method. Journal of Environmental Science and Health, Part A., 2012, 47(13):2151-2158

[29] Aukema K G, Escalante D E, Maltby M M, Bera A K, Aksan A, Wackett L P. In 
silicoidentification of bioremediation potential: Carbamazepine and other recalcitrant personal care products. Environmental Science and Technology, 2016, 51(2):880-888

\section{How to cite this article:}

Mohamad-Nasir N, Abdul-Talib S, Ismail H. N and Tay C. C.Biodegradation of carbamazepine using fungi and bacteria. J. Fundam. Appl. Sci., 2017, 9(6S), 124-146. 